\title{
K-252a, A POTENT INHIBITOR OF PROTEIN KINASE C FROM MICROBIAL ORIGIN
}

\author{
Hiroshi KaSE*, Kazuyuki Iwahashi and Yuzuru Matsuda \\ Tokyo Research Laboratories, Kyowa Hakko Kogyo Co., Ltd., \\ Machida-shi, Tokyo, Japan
}

(Received for publication February 6, 1986)

\begin{abstract}
K-252a, a metabolite isolated from the culture broth of Nocardiopsis sp. K-252a, was found to exhibit an extremely potent inhibitory activity on protein kinase $\mathrm{C}$. The $\mathrm{IC}_{50}$ value was $32.9 \mathrm{~nm}$.
\end{abstract}

The functional role of $\mathrm{Ca}^{2+}$ is well recognized as a second messenger for control of a variety of cell functions such as secretion, contraction, phototransduction, cell division and differentiation, and alteration of the transport of ions ${ }^{1)}$. Many of the effects of $\mathrm{Ca}^{2+}$ are transmitted by calmodulin, or other members of the same family of $\mathrm{Ca}^{2+}$ binding protein ${ }^{2 \sim 4)}$. In addition, the recent discovery of a phospholipid-sensitive $\mathrm{Ca}^{2+}$-dependent protein kinase (protein kinase $\mathrm{C}$ ) by NisHizuKA and coworkers ${ }^{5)}$ has led to a deeper understanding of how the $\mathrm{Ca}^{2+}$-messenger system operates. There appear to be two branches by which various extracellular informational signals flow from the cell surface to the cell interior ${ }^{6,7)}$. One is mediated by a rise in the $\left[\mathrm{Ca}^{2+}\right]$ concentration in the cell cytosol, leading to the modulation of the function of calmodulin-dependent reactions, the other by a rise in the diacylglycerol content of the plasma membrane, leading to the activation of protein kinase C. Both routes usually become available as the result of an interaction of a signal ligand and a receptor, and act synergistically to evoke subsequent cellular responses ${ }^{6)}$. Furthermore, the two branches may have unique roles in the temporal integration of cellular response in several cell types ${ }^{7}$.

In the course of studies on inhibitors or antagonists of the $\mathrm{Ca}^{2+}$-messenger system, we found that a novel metabolite of Nocardiopsis sp. K-252 inhibited protein kinase C and calmodulin. The compound, designated $\mathrm{K}-252 \mathrm{a}$ (previously named $\mathrm{K}-252$,) was isolated from the culture broth, and its structure was determined to be $\mathbf{1}^{8), \dagger}$ (Fig. 1). K-252a exhibited an extremely potent inhibitory activity of protein kinase $\mathrm{C}$. The compound also inhibited calmodulin-activated enzymes, although its effect on calmodulin was much less than that on protein kinase $\mathrm{C}$.

In this communication, we describe the fermentation, isolation and purification, and some biochemical properties of K-252a. Structural elucidation studies will be reported in a subsequent paper ${ }^{10)}$.

Fig. 1. The structure of K-252a (1).

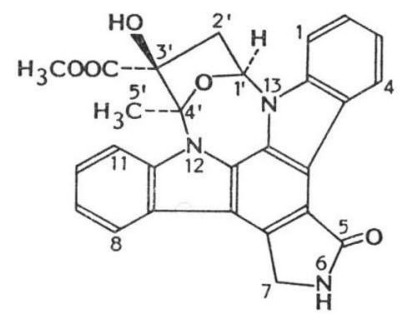

$\dagger$ Recently, SeZAKi et al ${ }^{9)}$ reported to isolate a compound SF-2370 from the culture broth of Actinomadura $\mathrm{sp}$; the structure of SF-2370 was identical to K-252a. 


\section{Materials and Methods}

\section{Materials}

Phosphatidylserine was purchased from Serdary Research Laboratories; diolein was from Nakarai Chemicals Ltd., Japan; $\left[\gamma^{-32}\right.$ P]ATP was from Amersham Corp.; histone H1 (type III-S, from calf thymus), cAMP, calmodulin and its dependent cyclic nucleotide phosphodiesterase (PDE) from bovine heart, and 5'-nucleotidase (Crotalus atrox venom) were from Sigma Chemical Co.

\section{Microorganisms}

Nocardiopsis sp. K-252 (NRRL 15532), isolated from a soil of Ashahi-cho, Machida-shi, Tokyo, Japan, was employed in the present investigation. Morphological, cultural and physiological characteristics of the strain will be described in detail elsewhere.

\section{Fermentation}

A culture tube containing $15 \mathrm{ml}$ of a seed medium composed of glucose $0.5 \%$, soluble starch $3.0 \%$, soybean meal $2.0 \%$, yeast extract $0.5 \%$, corn steep liquor $0.5 \%, \mathrm{CaCO}_{3} 0.3 \%(\mathrm{pH} 7.2$ before sterilization) was inoculated with the mycelia of the organism grown on agar slant. The composition of the agar slant medium (Hickey-Tresner) was as follows; soluble starch $1 \%, \mathrm{~N}-\mathrm{Z}$ amine type A $0.2 \%$, beef extract $0.1 \%$, yeast extract $0.1 \%$, and agar $2 \%(\mathrm{pH} 7.2)$. The inoculated tube was incubated on a reciprocating shaker $(300 \mathrm{rpm})$ at $28^{\circ} \mathrm{C}$ for 96 hours. A 4-ml-aliquot of the culture was inoculated into a $300-\mathrm{ml}$ Erlenmeyer flask containing $40 \mathrm{ml}$ of the same medium and incubated on a rotary shaker $(200 \mathrm{rpm})$ at $28^{\circ} \mathrm{C}$ for 72 hours. A 30 -ml-aliquot of the culture was transferred into a 2-liter Erlenmeyer flask containing $300 \mathrm{ml}$ of the same medium and incubated at $28^{\circ} \mathrm{C}$ for 120 hours. The microbial growth was used to inoculate a 30 -liter jar fermentor containing 18 liters of the same medium. Fermentation was carried out for 160 hours with agitation at 200 rpm and aeration of 18 liter/minute. K-252 production in the culture filtrate was quantified spectrophotometrically after developing the filtrate on TLC plate (Merck, Kieselgel $60 \mathrm{~F}_{254}, 5715$ ) with $\mathrm{CHCl}_{3}-\mathrm{MeOH}(9: 1)$. The plate was scanned at the wavelength of $292 \mathrm{~nm}$ with a Shimadzu Dual-wavelength TLC Scanner.

\section{Preparation of Protein Kinase C}

Protein kinase $\mathrm{C}$ was partially purified from rat brain cytosol by a modification of the procedures described by KIKKAWA et al. ${ }^{11}$. In brief, cerebral cortices of male Sprague-Dawley rats, weighing 150 to $200 \mathrm{~g}$, were homogenized in $20 \mathrm{~mm}$ Tris- $\mathrm{HCl}$ buffer ( $\mathrm{pH} 7.5$ ) containing sucrose $250 \mathrm{~mm}$, EDTA $2 \mathrm{~mm}$, EGTA $10 \mathrm{~mm}$ and phenylmethyl sulfonyl fluoride $2 \mathrm{~mm}$ (Buffer A). The homogenate was centrifuged at $100,000 \times g$ for 60 minutes at $-4^{\circ} \mathrm{C}$ and the supernatant was applied to a DE52 column (Whatman, $100 \mathrm{ml}$ ). The column was washed with $300 \mathrm{ml}$ of $20 \mathrm{~mm}$ Tris- $\mathrm{HCl}$ buffer (pH 7.5) containing EDTA 2 mM, EGTA $5 \mathrm{~mm}$, and 2-mercaptoethanol $50 \mathrm{~mm}$ (Buffer B) and then with the same buffer containing EDTA $1 \mathrm{~mm}$, EGTA $1 \mathrm{~mm}$ and 2-mercaptoethanol $50 \mathrm{~mm}$ (Buffer C). The enzyme was eluted by application of a $1,200 \mathrm{ml}$ linear gradient of $\mathrm{NaCl}(0$ to $0.3 \mathrm{M})$ in $\mathrm{Buffer} \mathrm{C}$ at a flow rate $75 \mathrm{ml} /$ hour. The fractions containing the enzyme were pooled and concentrated in an Amicon ultrafiltration cell equipped with PM-10 filter membrane. The concentrated enzyme was stored at $-80^{\circ} \mathrm{C}$ in the presence of $50 \%(\mathrm{w} / \mathrm{v})$ glycerol. By these procedures, protein kinase $\mathrm{C}$ was purified about 8.2 -fold from the crude extract with an overall recovery of about $14 \%$. The enzyme preparation contained no detectable cAMP- or cGMP-dependent protein kinase activity.

Preparation of Calmodulin and Its Dependent PDE from Bovine Brain

Calmodulin and its dependent PDE were partially purified from bovine brain by a modification of the procedures described by KAKIUCHI et al. ${ }^{12)}$. Cerebral cortices of bovine brain were homogenized in $10 \mathrm{~mm}$ Tris- $\mathrm{HCl}$ buffer ( $\mathrm{pH} 7.5$ ) containing $\mathrm{MgSO}_{4} 1 \mathrm{~mm}$, EGTA $0.1 \mathrm{~mm}$ and 2-mercaptoethanol $5 \mathrm{~mm}$. The homogenate was centrifuged at $24,000 \times g$ for 60 minutes at $0^{\circ} \mathrm{C}$ and the supernatant was centrifuged again at $113,000 \times g$ for 60 minutes. The final supernatant was applied to a DEAESephacel column (Pharmacia, $5 \times 30 \mathrm{~cm}$ ). The column was washed with $10 \mathrm{~mm}$ Tris-HCl buffer $(\mathrm{pH}$ 6.0) containing $\mathrm{MgSO}_{4} 1 \mathrm{~mm}$, EGTA $0.2 \mathrm{~mm}$ and 2-mercaptoethanol $5 \mathrm{~mm}$, and then eluted with a 
linear gradient of $\mathrm{CH}_{3} \mathrm{COONa}(0$ to $1 \mathrm{M}$ ) in the same buffer. The fractions containing calmodulin or its dependent PDE were pooled and concentrated by ultrafiltration through PM-10 membrane. The concentrated enzyme and calmodulin were dialyzed overnight against $20 \mathrm{~mm}$ Tris- $\mathrm{HCl}$ buffer $(\mathrm{pH} 7.5)$ containing $\mathrm{MgSO}_{4} 1 \mathrm{~mm}$, EGTA $0.1 \mathrm{~mm}$, 2-mercaptoethanol $5 \mathrm{~mm}$ and $\mathrm{NaCl} 100 \mathrm{~mm}$, and centrifuged at $27,000 \times g$ for 30 minutes. The supernatant was stored at $-80^{\circ} \mathrm{C}$ in small aliquots.

\section{Enzyme Assay and Determination}

Protein kinase $\mathrm{C}$ was assayed essentially as described by KIKKAWA et al. ${ }^{11)}$. Briefly, the incubation mixture $(0.25 \mathrm{ml})$ contained Tris- $\mathrm{HCl}$ buffer $(\mathrm{pH} 7.5) 5 \mu \mathrm{mol}$, magnesium acetate $2.5 \mu \mathrm{mol}$, histone H1 $50 \mu \mathrm{g},\left[\gamma^{-32} \mathrm{P}\right] \mathrm{ATP} 1.25 \mathrm{nmol}$, phosphatidylserine $20 \mu \mathrm{g}, 1,2$-diolein $0.8 \mu \mathrm{g}, \mathrm{CaCl}_{2} 0.75 \mu \mathrm{mol}$, EGTA $1 \mu \mathrm{mol}$, and the enzyme. After incubation at $30^{\circ} \mathrm{C}$ for 3 minutes, the reaction was stopped by the addition of $3 \mathrm{ml}$ of $25 \%$ trichloroacetic acid. The acid precipitates were collected on a Toyo-Roshi membrane filter, and the radioactivity of the filter was measured using liquid scintillation counter. To determine the effect of a drug on the enzyme activity, $5 \mu \mathrm{l}$ of the drug solution was added to the reaction mixture.

PDE activity was determined as described by KAKIUCHI et al. ${ }^{12)}$ based on the method of BUTCHER and SutherLAND ${ }^{13)}$. The reaction mixture contained, in a final volume of $0.5 \mathrm{ml}$, imidazole- $\mathrm{HCl}$ buffer ( $\mathrm{pH}$ 6.9) $80 \mathrm{~mm}, \mathrm{MgSO}_{4} 3 \mathrm{~mm}$, dithiothreitol $0.3 \mathrm{~mm}, \mathrm{NaCl} 100 \mathrm{~mm}$, cAMP $1.2 \mathrm{~mm}$ as a substrate, the enzyme (PDE) and other additions as indicated. The reaction was started by adding the enzyme. Incubation was carried out at $30^{\circ} \mathrm{C}$ for 30 minutes, and the reaction was stopped by boiling for 5 minutes. Then $6 \mu \mathrm{mol}$ of $\mathrm{MnCl}_{2}$ and a sufficient amount of $5^{\prime}$-nucleotidase was added and the mixture was incubated at $30^{\circ} \mathrm{C}$ for another 30 minutes. The reaction was terminated by adding $3 \mathrm{ml}$ of $10 \%$ perchloric acid, and the mixture was centrifuged at $1,300 \times g$ for 5 minutes. Inorganic phosphate liberated in the supernatant was measured by the method of AMES ${ }^{14)}$.

In the determination of the $\mathrm{Ca}^{2+} /$ calmodulin-activated activity (total activity), $\mathrm{CaCl}_{2}(50 \mu \mathrm{M})$ and calmodulin (as indicated in legends of Figs.) were added to the assay mixture. Basal activity was similarly determined, but in the presence of $3 \mathrm{~mm}$ EGTA instead of $\mathrm{Ca}^{2+}$ and calmodulin. The $\mathrm{Ca}^{2+} /$ calmodulin-activated activity was expressed in terms of total activity minus basal activity. In this investigation, a unit of PDE was defined as the amount which hydrolyses $1 \mu \mathrm{mol}$ of cAMP per minute at $30^{\circ} \mathrm{C}$ and a unit of calmodulin as the amount which gives $50 \%$ stimulation of PDE activity. To determine the effect of a drug on the enzyme activity, the drug solution $(50 \mu \mathrm{l})$ was added to the reaction mixture prior to the addition of the enzyme.

To determine the inhibitory effect of a drug on basal activity, a large amount of PDE (9.3 mu; unit definition was determined in the absence of calmodulin) was used to magnify PDE activity. The actual effect induced by the drug was corrected by subtracting the value obtained for the vehicle.

Protein was determined according to BRADFORD ${ }^{15}$.

\section{Results}

Fermentation, Isolation and Purification, and Physico-chemical Properties

Time course of K-252a production by Nocardiopsis sp. K-252 in a 30-liter jar fermentor is shown in Fig. 2. The amount of K-252a in the culture supernatant increased gradually from 0 to 120 hours of cultivation and then rapidly increased with the concomitant lysis of cells.

The procedure for isolation of K-252a is shown schematically in Fig. 3. Culture broth (15 liters) was centrifuged in a Sharples centrifuge. The supernatant was applied onto a Diaion HP-10 resin column ( 2 liters) and washed with 50\% methanol (4 liters), and then with $30 \%$ acetone ( 2 liters). Adsorbed material was eluted with acetone (4 liters). The eluate was concentrated in vacuo and extracted with ethyl acetate. The ethyl acetate layer was dried over $\mathrm{Na}_{2} \mathrm{SO}_{4}$ and then concentrated in vacuo to yield oily yellow material ( $4.9 \mathrm{~g}$ ). The oily material was applied to silica gel column chromatography. Elution was performed with chloroform, and then with chloroform-methanol (98:2). K-252a was 
Fig. 2. Time course of K-252a production in a $30-$ liter jar fermentor.

O; K-252a, ; $\mathrm{OD}_{660}$ (optical density at $660 \mathrm{~nm}$, the value of culture broth diluted 100-fold), $\mathbf{\Delta} ; \mathrm{pH}$.
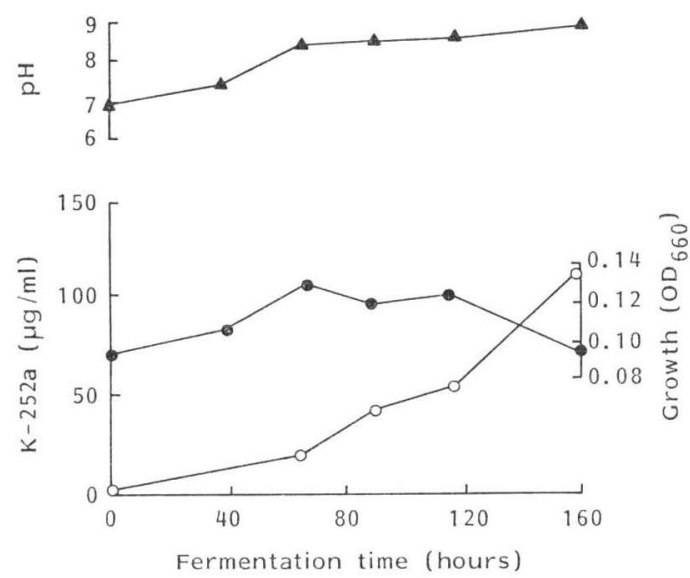

Fig. 3. Purification procedure of K-252a.

Culture broth (15 liters) centrifuged

Supernatant

|

Diaion HP-10 column chromatography (2 liters)

washed with $50 \% \mathrm{MeOH}$ (4 liters) and then $30 \%$ acetone ( 2 liters)

eluted with acetone (4 liters)

concd

extracted with EtOAc

EtOAc layer

$$
\begin{aligned}
& \text { dried over } \mathrm{Na}_{2} \mathrm{SO}_{4} \\
& \text { concd }
\end{aligned}
$$

Silica gel column chromatography

(Wakogel C-200, $150 \mathrm{ml}$ )

$$
\begin{aligned}
& \text { washed with } \mathrm{CHCl}_{3}(800 \mathrm{ml}) \\
& \text { eluted with } \mathrm{CHCl}_{3}-\mathrm{MeOH}(98: 2,700 \mathrm{ml})
\end{aligned}
$$

K-252a fractions *

concd

dissolved in $\mathrm{CHCl}_{3}$

\begin{tabular}{|c|c|}
\hline Appearance & Pale yellow crystals \\
\hline \multicolumn{2}{|l|}{ TLC* $*$ Rf) } \\
\hline $\mathrm{CHCl}_{3}$ & 0.5 \\
\hline EtOAc & $0.35 \sim 0.55$ \\
\hline $\mathrm{CHCl}_{3}-\mathrm{MeOH}(9: 1)$ & $0.6 \sim 0.7$ \\
\hline $\mathrm{MeOH}$ & $0.7 \sim 0.8$ \\
\hline \multicolumn{2}{|l|}{ Color reaction } \\
\hline Positive & Anisaldehyde \\
\hline Negative & $\begin{array}{l}\mathrm{FeCl}_{3}, \text { Ninhydrin, } \\
\text { Rydon-Smith }\end{array}$ \\
\hline \multicolumn{2}{|l|}{ Solubility } \\
\hline Soluble & $\begin{array}{l}\mathrm{CHCl}_{3} \text {, pyridine, THF, } \\
\mathrm{DMSO}, \mathrm{CH}_{3} \mathrm{CN} \text {, } \\
\mathrm{Me}_{2} \mathrm{CO}\end{array}$ \\
\hline Slightly soluble & $\begin{array}{l}\mathrm{MeOH}, \mathrm{EtOH}, \mathrm{EtOAc}, \\
\mathrm{BuOH}, \mathrm{PrOH}\end{array}$ \\
\hline Insoluble & $\mathrm{H}_{2} \mathrm{O}$ \\
\hline
\end{tabular}
added $\mathrm{MeOH}$

$\mathrm{K}-252 \mathrm{a}$ (pale yellow crystals, $610 \mathrm{mg}$ )
Table 1. Physico-chemical properties of K-252a.

Fig. 4. Inhibition of protein kinase $\mathrm{C}$ by K-252a. Assay conditions were as described under "Materials and Methods", with various concentrations of $\mathrm{K}-252 \mathrm{a}$ added as indicated.

Protein kinase C $(40 \mu \mathrm{g})$ was incubated $(0.25 \mathrm{ml})$ in the presence of EGTA $(1 \mu \mathrm{mol})$ with $(0)$ or without (), $\mathrm{CaCl}_{2}(0.75 \mu \mathrm{mol})$, phosphatidylserine $(20 \mu \mathrm{g})$ and diolein $(0.8 \mu \mathrm{g})$.

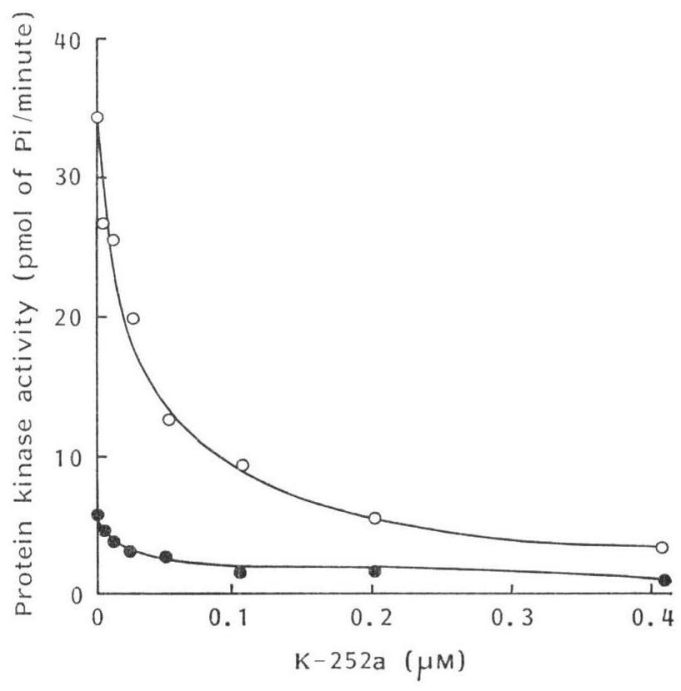

eluted with the latter. Fractions containing K-252a was collected and concentrated in vacuo to dryness. The yellow powder thus obtained was dissolved in chloroform and methanol was added. The solution was kept standing at $4^{\circ} \mathrm{C}$ to crystallize $\mathrm{K}-252 \mathrm{a}(610 \mathrm{mg})$.

$\mathrm{K}-252 \mathrm{a}$ was obtained as pale yellow crystals, melting at $262 \sim 273^{\circ} \mathrm{C}$. It is readily soluble in acetone, pyridine, chloroform, tetrahydrofuran, acetonitril and dimethyl sulfoxide, sparingly soluble in 
Table 2. Effect of K-252a on cyclic nucleotide phosphodiesterases.

\begin{tabular}{ccc}
\hline Enzymes & $\mathrm{CaM}^{*}$ & $\mathrm{IC}_{50}(\mu \mathrm{M})$ \\
\hline Bovine brain CaM-PDE** & $+^{\mathrm{a}}$ & 2.9 \\
Bovine heart CaM-PDE** & $-{ }^{\mathrm{b}}$ & $>200$ \\
Bovine heart CaM-independent PDE & $+^{\mathrm{c}}$ & 1.3 \\
\hline
\end{tabular}

a The activity in the presence of $4 \mathrm{U} / \mathrm{ml}$ calmodulin, and $50 \mu \mathrm{M} \mathrm{CaCl}_{2}$. The enzyme concentration was $26 \mathrm{mu} / \mathrm{ml}$.

b The activity in the presence of $3 \mathrm{~mm}$ EGTA, without $\mathrm{CaCl}_{2}$ and calmodulin. The enzyme concentration was $18.6 \mathrm{mu} / \mathrm{ml}$.

c The activity in the presence of $2.5 \mathrm{U} / \mathrm{ml}$ calmodulin, and $50 \mu \mathrm{M} \mathrm{CaCl}_{2}$. The enzyme concentration was $40 \mathrm{mu} / \mathrm{ml}$.

d The activity in the presence of $3 \mathrm{~mm}$ EGTA, without $\mathrm{CaCl}_{2}$ and calmodulin. The enzyme concentration was $25 \mathrm{mu} / \mathrm{ml}$.

* Calmodulin. ** $\mathrm{Ca}^{2+} /$ calmodulin-dependent phosphodiesterase.

alcohol and ethyl acetate, and virtually insoluble in water. The Rf values of the compound on silica gel TLC developed in various solvent systems are shown in Table 1. The structure of K-252a was determined to be $\mathbf{1}$ (Fig. 1) on the basis of physico-chemical analyses, and various spectral and X-ray crystallographic data ${ }^{10)}$.

\section{Biochemical Properties}

Fig. 4 shows the effect of various concentrations of $\mathrm{K}-252 \mathrm{a}$ on protein kinase $\mathrm{C}$ from rat brain. $\mathrm{K}-252 \mathrm{a}$ inhibited the $\mathrm{Ca}^{2+} /$ phospholipid-dependent activity of the enzyme in a concentration-related manner. The $\mathrm{IC}_{50}$ value, (the concentration causing $50 \%$ inhibition), under present assay conditions, was 32.9 nм. Basal activity of the enzyme (the activity in the absence of $\mathrm{Ca}^{2+}$, phosphatidylserine and diolein) was inhibited similarly by K-252a.

K-252a inhibited $\mathrm{Ca}^{2+} /$ calmodulin-stimulated PDE's from bovine brain and heart (Table 2). The activity of K-252a for calmodulin was much less than that for protein kinase $\mathrm{C}$. The $\mathrm{IC}_{50}$ values for the effect of the enzymes were; brain PDE, $2.9 \mu \mathrm{M}$ and heart PDE, 1.3 $\mu \mathrm{M}$. K-252a inhibited specifically the $\mathrm{Ca}^{2+} /$ calmodulin-dependent activities of the enzymes without appreciably affecting their basal activities. In addition, calmodulin-independent PDE from bovine heart was only weakly inhibited by $\mathrm{K}-252 \mathrm{a}\left(\mathrm{IC}_{50}\right.$ value, $\left.97.5 \mu \mathrm{M}\right)$.

$\mathrm{K}-252 \mathrm{a}$ at $100 \mu \mathrm{g} / \mathrm{ml}$ exhibited no antimicrobial activity against Candida albicans KY5011, Enterococcus faecalis KY4280, Pseudomonas aeruginosa KY4276, Staphylococcus aureus KY4779, Escherichia coli KY4271, Bacillus subtilis KY4773, Proteus vulgaris KY4277, Shigella sonnei KY4281, Salmonella typhosa KY4278, or Klebsiella pneumoniae KY4275.

No acute toxicity of the compound was observed at $100 \mathrm{mg} / \mathrm{kg}$ in mice injected intraperitoneally.

\section{Discussion}

Several kinds of compounds have been reported to inhibit protein kinase C. A variety of lipidinteracting agents including chlorpromazine, imipramine, phentolamine, dibucaine, verapamil and tetracaine are able to inhibit protein kinase $\mathrm{C}^{18)}$ to various degrees. Phenothiazines ${ }^{17}{ }^{18}$, such as trifluoperazine and chlorpromazine, $N$-(6-aminohexyl)-5-chloronaphthalenesulfonamide (W-7 $)^{19 \sim 21)}$, and R-24571 (calmidazolium)22), known as calmodulin inhibitors, have also been shown recently to inhibit protein kinase C. From these observations, Schatzman et al. ${ }^{23)}$ suggested that there appeared 
to be little selectivity for inhibition of $\mathrm{Ca}^{2+} /$ calmodulin- or $\mathrm{Ca}^{2+} /$ phospholipid-dependent enzyme by these agents. More recently, HidAKA et al. ${ }^{24)}$ reported that isoquinolinesulfonamides, such as H-7, inhibit protein kinase $\mathrm{C}$ and cyclic nucleotide-dependent protein kinases, competing with ATP. Now, we have found that K-252a, a novel metabolite isolated from Nocardiopsis $\mathrm{sp}$. K-252, inhibits protein kinase C. K-252a appears to be the most potent inhibitor of protein kinase $\mathrm{C}$ ever reported; the $\mathrm{IC}_{50}$ value for K-252a was $32.9 \mathrm{~nm}$, which is two or three orders of magnitude lower than that for the protein kinase $\mathrm{C}$ inhibitors described above (the $\mathrm{IC}_{50}$ values for $\mathrm{H}-7$, trifluoperazine, chlorpromazine, and R-24571 were 12, 16, 24 and $5.3 \mu \mathrm{M}$, respectively, under comparable incubation conditions). Furthermore, the inhibitory effects by K-252a seem to be attributed to the direct interaction of the compound with the enzyme, and not with the enzyme activators, as suggested by its inhibition of the basal activity of the enzyme. Detailed kinetic analysis will be described in a separate paper. Whether K252a inhibits other protein kinases such as cAMP- and cGMP- dependent protein kinases, remains to be determined. The inhibitory specificity of $\mathrm{K}-252 \mathrm{a}$ for protein kinases is under investigation.

$\mathrm{K}-252 \mathrm{a}$ also inhibits calmodulin. Although the inhibitory activity for calmodulin is much less than that for protein kinase $\mathrm{C}$, it may be of interest to determine whether or how these calmodulinantagonistic properties contribute to the in vitro or in vivo pharmacological effect of $\mathrm{K}-252 \mathrm{a}$ on $\mathrm{Ca}^{2+}$ messenger systems in various cells and tissues. We have found that $\mathrm{K}-252 \mathrm{a}$ seriously affects the function of various cells and tissues, such as platelets ${ }^{25)}$, mast cells ${ }^{8)}$ and vascular smooth muscle. This newly developed compound may be a useful tool for clarifying the in vitro and in vivo functions of protein kinases and/or calmodulin.

\section{References}

1) Rubin, R. P.: Historical and biological aspects of calcium action. In Calcium in Biological Systems. Ed., R. P. Rubin et al., pp. 5 11, Plenum Press, New York, 1985

2) KaKIUCHI, S. \& R. YAMAZAKI: Calcium dependent phosphodiesterase activity and its activating factor (PAF) from brain. Biochem. Biophys. Res. Commun. 41: 1140 1110, 1970

3) Cheung, W. Y.: Cyclic 3',5'-nucleotide phosphodiesterase. Demonstration of an activator. Biochem. Biophys. Res. Commun. 38: 533 538, 1970

4) Cheung, W. Y.: Calmodulin plays a pivotal role in cellular regulation. Science 207: 19 27, 1980

5) Takai, Y.; A. Kishimoto, Y. Iwasa, Y. Kawahara, T. Mori \& Y. Nishizuka: Calcium-dependent activation of multifunctional protein kinase by membrane phospholipids. J. Biol. Chem. 254: 3692 3695,1979

6) NishizuKa, Y.: Turnover of inositol phospholipids and signal transduction. Science 225: 1365 1370, 1984

7) Rasmussen, H.; I. Kojima, K. Kojima, W. Zawalich \& W. Apfeldorf: Calcium as intracellular messenger: Sensitivity modulation, C-kinase pathway, and sustained cellular response. In Adv. Cyclic $\mathrm{Nu}-$ cleotide and Protein Phosphorylation Research. Vol. 18, Eds., P. Greengard \& G. A. Robison, pp. 159 193, Raven Press, New York, 1984

8) Matsuda, Y.; K. Iwahashi, T. Iida, N. Hirayama, I. Asano, K. Shuto, K. Yamada, K. Shirahata \& H. KASE (Kyowa Hakko): A novel physiologically active substance K-252 and process for producing same. Jpn. Kokai 41489 (85'), Mar. 5, 1985

9) Sezaki, M.; T. Sakaki, T. Nakazawa, U. Takeda, M. Iwata, T. Watanabe, M. Koyama, F. Kai, T. Shomura \& M. Koлma: A new antibiotic SF-2370 produced by Actinomadura. J. Antibiotics 38: 1437 1439,1985

10) Yasuzawa, T.; T. Iida, M. Yoshida, N. Hirayama, M. Takahashi, K. Shirahata \& H. Sano: The structures of the novel protein kinase C inhibitors K-252a, b, c and d. J. Antibiotics 39: 1072 1078, 1986

11) Kikkawa, U.; Y. Takai, R. Minakuchi, S. Inohara \& Y. Nishizuka: Calcium-activated, phospholipiddependent protein kinase from rat brain. J. Biol. Chem. 257: 13341 13348, 1982

12) Kakiuchi, S.; R. Yamazaki, Y. Teshima, K. Uenishi \& E. Miyamoto: Multiple cyclic nucleotide phosphodiesterase activities from rat tissues and occurrence of calcium-plus-magnesium-ion-dependent phosphodiesterase and its protein activator. Biochem. J. 146: 109 120, 1975

13) Butcher, R. W. \& E. W. Sutherland: Adenosine 3',5'-phosphate in biological materials I. Purifications and properties of cyclic $3^{\prime}, 5^{\prime}$-nucleotide phosphodiesterase and use of this enzyme to characterize adenosine 3',5'-phosphate in human urine. J. Biol. Chem. 237: 1244 1250, 1962 
14) Ames, B. N.: Assay of inorganic phosphate, total phosphate and phosphatases. In Method in Enzymology. Vol. 8. Eds., E. F. Neufeld \& V. Ginsburg, pp. 115 116, Academic press, New York, 1966

15) BRADFORD, M.: A rapid and sensitive method for the quantitation of microgram quantities of protein utilizing the principle of protein-dye binding. Anal. Biochem. 72: 248 254, 1976

16) Mori, T.; Y. TAKaI, R. Minakuchi, B. YU \& Y. Nishizuka: Inhibitory action of chlorpromazine, dibucaine, and other phospholipid-interacting drugs on calcium-activated, phospholipid-dependent protein kinase. J. Biol. Chem. 255: 8378 8380, 1980

17) Schatzman, R. C.; B. C. Wise \& J. F. Kuo: Phospholipid-sensitive calcium-dependent protein kinase: Inhibition by antipsychotic drugs. Biochem. Biophys. Res. Commun. 98: 669 676, 1981

18) WRENN, R. W.: Inhibition by phenothiazine antipsychotic drugs of calcium-dependent phosphorylation of cerebral cortex proteins regulated by phospholipid or calmodulin. Life Sci. 29: 725 733, 1981

19) Turner, R. S.; C.-H. J. Chou, R. F. Kibler \& J. F. Kuo: Basic protein in brain myelin is phosphorylated by endogenous phospholipid-sensitive calcium-dependent protein kinase. J. Neurochem. 39: 1397 1404, 1982

20) Tanaka, T.; T. Ohmura, T. Yamakado \& H. Hidaka: Two types of calcium-dependent protein phosphorylations modulated by calmodulin antagonists. Mol. Pharmacol. 22: 408 412, 1982

21) Schatzman, R. C.; R. L. Raynor \& J. F. Kuo: N-(6-aminohexyl)-5-chloro-1-naphthalenesulfonamide (W-7), a calmodulin antagonist, also inhibits phospholipid-sensitive calcium-dependent protein kinase. Biochim. Biophys. Acta 755: $144 \sim 147,1983$

22) Mazzei, G. J.; R. C. Schatzman, R. S. Turner, W. R. Vogler \& J. F. Kuo: Phospholipid-sensitive $\mathrm{Ca}^{2+}$-dependent protein kinase inhibition by R-24571, a calmodulin antagonist. Biochem. Pharmacol. $33: 125 \sim 130,1984$

23) Schatzman, R. C.; R. S. Turner \& J. F. Kuo: Phospholipid-sensitive $\mathrm{Ca}^{2+}$-dependent protein phosphorylation. In Calcium and Cell Function. Vol. V. Ed., W. Y. Cheung, pp. 33 66, Academic Press, New York, 1984

24) Hidaka, H.; M. Inagaki, S. Kawamoto \& Y. Sasaki: Isoquinolinesulfonamides, novel and potent inhibitors of cyclic nucleotide dependent protein kinase and protein kinase C. Biochemistry 23: 5036 5041,1984

25) Yamada, K.; H. Kase \& K. Kubo: Effect of a new microbial metabolite, K-252, on secretion and aggregation in rabbit platelets. Jpn. J. Pharmacol. 40 (Supple): 265, 1986 